\title{
Biofortification of the Ryegrass (Lolium multiflorum L.) with Chicken Manure Compost in the Central Sierra of Peru
}

\author{
Doris Chirinos-Peinado $^{1^{*}}$, Jorge Castro-Bedriñana ${ }^{1}$, Percy Lara-Schwartz ${ }^{2}$

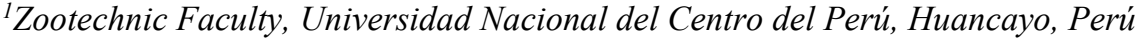 \\ ${ }^{2}$ Agrarian Agency of Jauja, Ministry of Agriculture. Junín, Perú
}

\begin{tabular}{l} 
A R T I C L E I N F O \\
\hline Article history: \\
Received: 01 December, 2019 \\
Accepted: 18 December, 2019 \\
Online: 25 February, 2020
\end{tabular}

Keywords:

Composting

Manure chicken

Organic fertilizer

Forage quality

Italian ryegrass

\begin{abstract}
A B S T R A C T
In Peru, large volumes of chicken manure are produced, whose compost applied at normal levels improves the ryegrass yield and protein intake, to obtain organic products and contribute to animal, environmental and human health. To evaluate the biofortifying effect of Chicken Manure Compost (CMC) incorporated in (T1): 0, (T2): 10 and (T3): 20 tha -1 $^{-1}$ levels, on Green Forage (GF) yield, Dry Matter (DM), Total Protein (TP) and Plant Height (PH) of Italian ryegrass, in pasture located in Huancayo, Peru (3250 altitude); two cuts were made, the first one was 42 days after the first fertilization and the second was 42 days after the first cut and second fertilization. In second cut, GF yield, in T1, T2 and T3 was

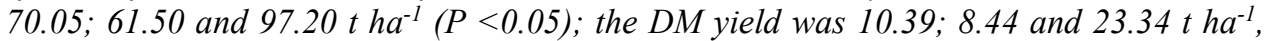
respectively $(P<0.05)$; TP yield was $1.76 ; 1.74$ and $2.80 \mathrm{t} \mathrm{ha}^{-1}$, respectively $(P<0.05)$ and the $P H$ was $97.0 ; 93.8$ and $99.63 \mathrm{~cm}$, respectively $(P<0.05)$. The application of $10 \mathrm{th} \mathrm{h}^{-1}$ had no greater effect in front of the control. The use of $20 \mathrm{tha}^{-1}$ of CMC allows to obtain organic forage with higher yield of dry matter and protein and therefore it is possible to obtain organic livestock products, with the advantage of reducing the negative impact of bird manure to public health, when is traditionally eliminated to environment.
\end{abstract}

\section{Introduction}

The livestock sector is the world's largest consumer of agricultural land, through grazing and use of forage crops; however, about $20 \%$ of pastures have deteriorated due to overgrazing and compaction [1].

Among the most used pastures, ryegrass, in association with alfalfa and clover, are important for feeding cattle and other herbivorous species; in the inter-Andean valleys of Peru they have a useful life of 3 to 5 years, with a biomass production of high nutritional quality [2].

In the Junín region, the area of natural pastures is $1,104300.04$ ha. [3]; 29,649.30 ha are corresponding to cultivated pastures, of which 27,633.20 ha are in the Junín mountain range [3]. The production of ryegrass in 2018 was 196,384 tons and the harvested area was 6,656 ha, with a yield of 29.5 ton ha-1 [4].

\footnotetext{
${ }^{*}$ Doris Chirinos-Peinado, Av. Mariscal Castilla 3909, El Tambo-Huancayo, +51 924855954\&dchirinos@uncp.edu.pe
}

Generally, the improvement of forage production seeks to increase biomass yield and productivity, mainly evaluating the yield of green forage, dry matter and in some cases the plant height; however, it is important to evaluate the nutritional composition, especially the yield and quality of protein. To improve the nutritional contribution, different technological strategies can be used, including agronomic biofortification of basic foods, a process that improves the concentration of one or more nutrients in the edible part of the crop, by applying nutrientrich fertilizers to the soil or foliage to improve the concentration of micronutrients in the edible part of the crop [5, 6]. Biofortification of ryegrass, through the application of Chicken Manure Compost has enormous potential, as has been reported in the improvement of the contribution of selenium in rice $[7,8]$.

Italian Ryegrass (Lolium multiflorum L.), is a grass of high productive potential, yields more than $10 \mathrm{t} \mathrm{ha}^{-1}$ of dry matter of high taste and digestibility, producing up to 6 crops per year, which can be used as green, dehydrated forage or preserved as silage, for which it requires a soil rich in organic matter, especially nitrogen 
[9]; increasing the yield from $4.37 \mathrm{t} \mathrm{ha}^{-1}$ to $9.81 \mathrm{t} \mathrm{ha}^{-1}\left(5.44 \mathrm{t} \mathrm{ha}^{-1}\right.$ more) with application of $\mathrm{N}_{200}$ than with $\mathrm{N}_{0}$ [10].

Traditional fertilization, based on the contribution of nitrogen, phosphorus and potassium, in addition to having a short-term effect [11], affects the physicochemical and microbiological characteristics of the soil; its unbalanced use increases the degradation processes by reducing the organic fraction, causing adverse effects on the flora and fauna of the soil [12]; in addition, its use is increasingly expensive [13] and is not ecologically sustainable, and must be complemented or replaced by organic fertilizers, which improve the nutritional quality of biomass, soil quality and reduce waste contamination chemists $[13,14]$.

The meat chickens manure constituted by feces, urine, food waste and the material used as a bed, is eliminated causing a negative environmental impact on the air, soil and surface water bodies [15], as an alternative it can be used as compost in soil biofortification, having a series of beneficial effects, the first is the supply of nutrients to plants, improving yield and nutritional quality [16]. The aerobic stabilization of chicken manure, through composting, allows obtaining a quality fertilizer and at the same time contributes to the reduction of environmental pollution [17].

In Peru, the chicken meat production is an important industry; which production is above 150 thousand tons per year, has allowed increasing the per capita consumption of chicken meat from 20 to more than $40 \mathrm{~kg}$ per person per year between 2000-2016 [18]. In 2018 , the average annual consumption of chicken meat was $47 \mathrm{~kg}$ and for 2019 it is expected to be $49 \mathrm{~kg}$ [19]; and manure generated by this industry can be used as a nitrogen source and organic matter in agricultural production.

Chicken manure is made up of excretes, food waste, feathers and other bed materials; its $\mathrm{N}$ content results from the approximate combination of $70 \%$ uric acid and $30 \%$ undigested protein $[20,21]$. The percentage of nitrogen potentially available in manure from meat chicken, after 7 days of incubation, is $66 \%$, being a very good source of $\mathrm{N}$ [22].

The Chicken Manure Compost (CMC), called soil improver, is being used in the fertilization of parks, gardens and ornamental plants; it is obtained from the controlled decomposition of manure from broiler chickens, and can be used for the production of organic forage, improving its quality and soil [23].

Composting is done in aerobic conditions, avoiding the emission of $\mathrm{CO}_{2}$, ammonia and other volatile compounds into the atmosphere. It has between 20 to $30 \%$ of humidity; 7.0 to 8.5 of $\mathrm{pH} ; 23.8 \%$ organic matter; $1.1 \%$ of nitrogen; $1.9 \%$ of $\mathrm{P}_{2} \mathrm{O}_{5} ; 3.4 \%$ of $\mathrm{K}_{2} \mathrm{O} ; 5.1 \%$ of $\mathrm{CaO} ; 1.5 \%$ of $\mathrm{MgO} ; 0.6 \%$ of $\mathrm{Na} ; 61 \mathrm{ppm}$ of boron; 48ppm of Cu; 285ppm of Zn; 565 ppm of Mn y $13005 \mathrm{ppm}$ of Fe; it is free of pseudomonas, Salmonella and fecal bacteria.

Based on the above and the limited information on the behavior of $\mathrm{CMC}$ in the yield and nutritional quality of ryegrass, the objective of this research was to determine the yield of biomass, dry matter and total protein, and the height of Italian ryegrass plant, by incorporating 0,10 and $20 \mathrm{tha}^{-1}$ of CMC, to obtain organic and biofortified protein forage, which contributes to obtaining safe animal products that promote animal, environmental and human health.

\section{Materials and methods}

\subsection{Research site and observations}

The research was carried out in a six-month-old Italian ryegrass pasture, located in the Yauris experimental farm of the Universidad Nacional del Centro del Perú (UNCP), HuancayoJunín province (3250 altitude). The experiment lasted 12 weeks, making a first fertilization at the beginning of the experiment and a second fertilization at the sixth week, date on which the second cut of the ryegrass pasture was made, an approximate extension of $1250 \mathrm{~m}^{2}$, there were located three plots of ryegrass, $160 \mathrm{~m}^{2}$ each.

The first plot was considered as a Control treatment (T1): without fertilization or insemination, the second plot was fertilized with CMC (T2): $10 \mathrm{tha}^{-1}$ and the third one was fertilized with CMC (T3): $20 \mathrm{t} \mathrm{ha}^{-1}$. Two fertilizations were made, the first at the beginning of the experiment, with a first forage cut 42 days after the first fertilization. The second fertilization was made after the first cut and 42 days were expected to make the second cut for the final evaluation of the study parameters. These cutting periods answer to recommendations made for the Mantaro Valley (Junín, Peru), the range of the optimal rest period being 22 to 46 days for cultivated pastures [24].

Figure 1 shown the sequence of the investigation process.

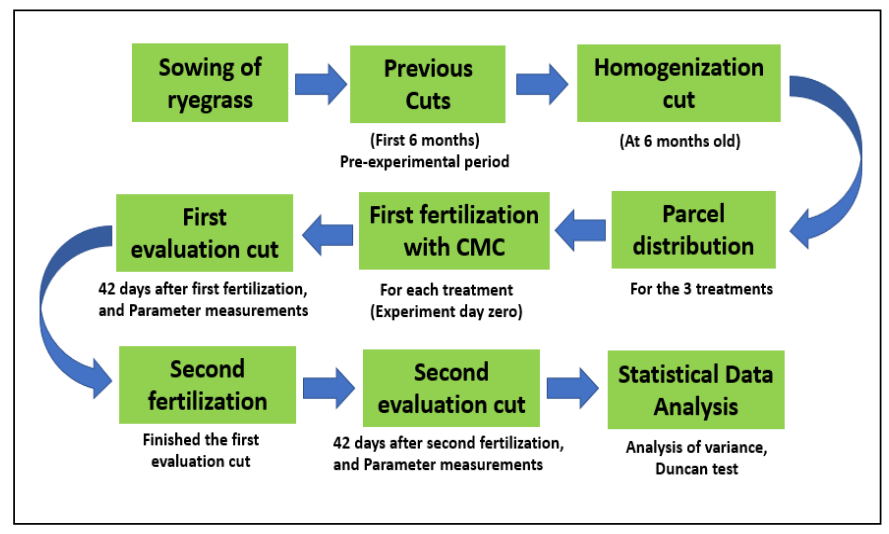

Figure 1: Research procedure secuence

\subsection{Sampling and proximal analysis}

The study was planned as randomized design with four repetitions, no difference of planting area. To evaluate the yield of green fodder, dry matter and protein in $\mathrm{kg} \mathrm{m}^{-2}$, and of the plant height $(\mathrm{cm})$, in each cut, four samples of $1 \mathrm{~m}^{2}$ parcela ${ }^{-1}$, were taken, being a cutting intensity of $5 \mathrm{~cm}$ [25]. Possible weeds were separated, and the weight of the ryegrass was recorded; subsequently, $100 \mathrm{~g}$ samples (fresh weight) were taken on an analytical balance and dried in an oven at $65^{\circ} \mathrm{C}$ for 72 hours. The dry matter (DM) and total protein (TP) content of the ryegrass samples was determined in the Animal Nutrition Laboratory of the Faculty of Zootechnics of the UNCP, following the protocols described by the AOAC [26].

\subsection{Plant Height (PH)}

The PH, before each cut, was measured with a flexometer, for which 10 plants were taken at random per sample per plot. The 
cutting intensity was $5 \mathrm{~cm}$ from the ground to the last leaf of the stem.

\subsection{Statistical analysis}

Variance analyzes were performed to determine the statistical differences between the studied variables, under a completely randomized design with three treatments and four repetitions per treatment. The differences between averages per variable were analyzed with Duncan significance tests with a $P<0.05$. Statistical processing was performed in SPSS v23.

\section{Results}

The use of 10 and $20 \mathrm{t} \mathrm{ha}^{-1}$ of Chicken Manure Compost (CMC) significantly affected the productive parameters of the ryegrass, being the first cut at 42 days after the first fertilization (Table 1 and Figure 2) and the second cut, at 42 days after the second fertilization (Table 2 and Figure 3).

Table 1. Production parameters of Italian ryegrass after 42 days of the first fertilization

\begin{tabular}{|c|c|c|c|c|c|}
\hline \multirow{2}{*}{ Parameters } & \multirow{2}{*}{ Treatments } & \multirow{2}{*}{ Average } & \multirow{2}{*}{$\begin{array}{l}\text { Standard } \\
\text { Deviation }\end{array}$} & \multicolumn{2}{|c|}{$\begin{array}{c}95 \% \text { of the IC for } \\
\text { average }\end{array}$} \\
\hline & & & & $\begin{array}{l}\text { Lower } \\
\text { Limit }\end{array}$ & $\begin{array}{l}\text { Upper } \\
\text { Limit }\end{array}$ \\
\hline \multirow{4}{*}{$\begin{array}{l}\text { GF yield, } \\
\mathrm{kg} / \mathrm{m}^{2}\end{array}$} & T1: CMC $0 \mathrm{t} \mathrm{ha}^{-1}$ & $7,600 \mathrm{a}$ & 1,105 & 5,842 & 9,358 \\
\hline & ${ }_{1}^{\mathrm{T}} 2: \mathrm{CMC} 10 \mathrm{tha}^{-}$ & $7,475 \mathrm{a}$ & 0,785 & 6,226 & 8,724 \\
\hline & ${ }_{1}^{\text {T3: CMC } 20 \mathrm{t} \mathrm{ha}^{-}}$ & $7,575 \mathrm{a}$ & 1,417 & 5,320 & 9,830 \\
\hline & Total & 7,550 & 1,026 & 6,898 & 8,202 \\
\hline \multirow{4}{*}{$\begin{array}{l}\text { DM yield } \\
\mathrm{kg} / \mathrm{m}^{2}\end{array}$} & T1: CMC $0 \mathrm{tha}^{-1}$ & $1,223 b$ & 0,177 & 0,940 & 1,505 \\
\hline & ${ }_{1}^{\mathrm{T}} 2: \mathrm{CMC} 10 \mathrm{tha}^{-}$ & $1,183 b$ & 0,125 & 0,984 & 1,381 \\
\hline & ${ }_{1}^{\text {T3: CMC } 20 \mathrm{tha}^{-}}$ & $2,153 \mathrm{a}$ & 0,401 & 1,515 & 2,790 \\
\hline & Total & 1,519 & 0,525 & 1,186 & 1,853 \\
\hline \multirow{4}{*}{$\begin{array}{l}\text { TP yield, } \\
\mathrm{kg} / \mathrm{m}^{2}\end{array}$} & T1: CMC $0 \mathrm{t} \mathrm{ha}^{-1}$ & $0,191 \mathrm{a}$ & 0,028 & 0,147 & 0,235 \\
\hline & ${ }_{1}^{\mathrm{T} 2:} \mathrm{CMC} 10 \mathrm{tha}-$ & $0,212 \mathrm{a}$ & 0,022 & 0,177 & 0,247 \\
\hline & ${ }_{1}^{\text {T3: CMC } 20 \mathrm{t} \mathrm{ha}^{-}}$ & $0,219 \mathrm{a}$ & 0,041 & 0,153 & 0,284 \\
\hline & Total & 0,207 & 0,031 & 0,188 & 0,227 \\
\hline \multirow{4}{*}{$\begin{array}{l}\text { Plant } \\
\text { Height, cm }\end{array}$} & T1: CMC $0 \mathrm{tha}^{-1}$ & $76,45 b$ & 2,460 & 72,536 & 80,364 \\
\hline & ${ }_{1}^{\mathrm{T} 2:}$ CMC $10 \mathrm{tha}^{-}$ & $83,51 \mathrm{a}$ & 0,782 & 82,267 & 84,758 \\
\hline & $\underset{1}{\mathrm{~T}} 3: \mathrm{CMC} 20 \mathrm{tha}^{-}$ & $84,27 \mathrm{a}$ & 2,227 & 80,731 & 87,819 \\
\hline & Total & 81,41 & 4,088 & 78,815 & 84,010 \\
\hline
\end{tabular}

Means per parameter with different letters are statistically different (Duncan, $P<0.05$ )

\section{Discussion}

\subsection{Green Forage (GF) yield}

The yield of GF after 42 days of the first fertilization with $\mathrm{CMC}$, does not register significant differences $(P>0.05)$, and sufficient time must pass so that the organic matter and all the nutrients of the fertilizer are progressively processed by the microorganisms of the soil to have a soil improvement effect, as shown in the results obtained after a second application of the $\mathrm{CMC}$ in the second cut. The organic phosphorus has to be released by mineralization for plants to absorb it; similarly, the nitrogen that is generally in organic form $(>95 \%)$, must evolve to nitrates, to provide nitrogen available for plants in the short term $[27,28]$.

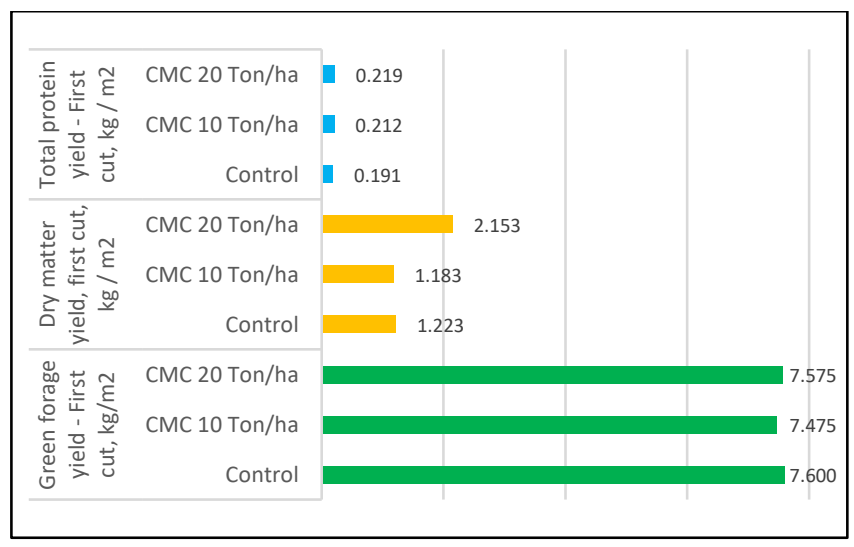

Figure 2: Productive parameters at the first cut, after 42 days of the first fertilization with chicken manure compost (CMC)

Table 2. Production parameters of the Italian ryegrass after 42 days of the second fertilization

\begin{tabular}{|c|c|c|c|c|c|}
\hline \multirow{3}{*}{ Parameters } & \multirow{3}{*}{ Treatments } & \multirow{3}{*}{ Average } & \multirow{3}{*}{$\begin{array}{l}\text { Standard } \\
\text { Deviation }\end{array}$} & \multicolumn{2}{|c|}{$\begin{array}{c}95 \% \text { of the IC for } \\
\text { average }\end{array}$} \\
\hline & & & & Lower & Upper \\
\hline & & & & Limit & Limit \\
\hline \multirow{4}{*}{$\begin{array}{l}\text { GF yield, } \\
\mathrm{kg} / \mathrm{m}^{2}\end{array}$} & T1: CMC 0 tha $^{-1}$ & $7,005 \mathrm{~b}$ & 0,695 & 5,899 & 8,111 \\
\hline & T2: CMC $10 \mathrm{tha}^{-1}$ & $6,150 \mathrm{~b}$ & 0,628 & 5,150 & 7,150 \\
\hline & T3: CMC $20 \mathrm{tha}^{-1}$ & $9,720 \mathrm{a}$ & 1,054 & 8,042 & 11,397 \\
\hline & Total & 7,625 & 1,752 & 6,512 & 8,738 \\
\hline \multirow{4}{*}{$\begin{array}{l}\text { DM yield } \\
\mathrm{kg} / \mathrm{m}^{2}\end{array}$} & T1: CMC 0 tha $^{-1}$ & $1,039 b$ & 0,103 & 0,876 & 1,203 \\
\hline & T2: CMC $10 \mathrm{tha}^{-1}$ & $0,844 b$ & 0,086 & 0,706 & 0,981 \\
\hline & T3: CMC $20 \mathrm{tha}^{-1}$ & $2,334 \mathrm{a}$ & 0,253 & 1,931 & 2,737 \\
\hline & Total & 1,406 & 0,707 & 0,957 & 1,855 \\
\hline \multirow{4}{*}{$\begin{array}{l}\text { TP yield, } \\
\mathrm{kg} / \mathrm{m}^{2}\end{array}$} & $\mathrm{~T} 1: \mathrm{CMC} 0 \mathrm{tha}^{-1}$ & $0,176 \mathrm{~b}$ & 0,017 & 0,149 & 0,203 \\
\hline & T2: CMC $10 \mathrm{tha}^{-1}$ & $0,174 \mathrm{~b}$ & 0,018 & 0,146 & 0,203 \\
\hline & T3: CMC $20 \mathrm{tha}^{-1}$ & $0,280 \mathrm{a}$ & 0,030 & 0,233 & 0,328 \\
\hline & Total & 0,210 & 0,555 & 0,175 & 0,245 \\
\hline \multirow{3}{*}{$\begin{array}{l}\text { Plant } \\
\text { height, cm }\end{array}$} & T1: CMC 0 tha $^{-1}$ & $97,05 \mathrm{ab}$ & 2,093 & 93,718 & 100,381 \\
\hline & T2: CMC $10 \mathrm{t} \mathrm{ha}^{-1}$ & $93,82 b$ & 3,897 & 87,622 & 100,027 \\
\hline & T3: CMC $20 \mathrm{tha}^{-1}$ & $99.63 \mathrm{a}$ & 3,901 & 93,422 & 105,838 \\
\hline
\end{tabular}


D. Chirinos et al. I Advances in Science, Technology and Engineering Systems Journal Vol. 5, No. 1, 418-423 (2020)

Total $\quad 86.83 \quad 3.954 \quad 94,322 \quad 99,348$

Means per parameter with different letters are statistically different

(Duncan, $\mathrm{p}<0.05$ )

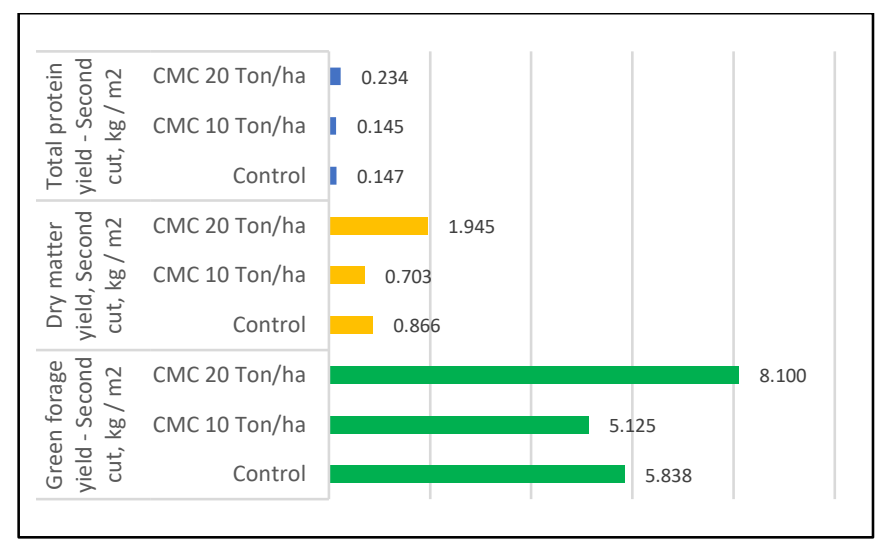

Figure 3: Productive parameters at the second cut, after 42 days of the second fertilization with CMC

The yield of GF $\mathrm{m}^{-2}$, by treatment, after 42 days after the first cut (lapsed 84 days), shows significant differences $(\mathrm{P}<0.05)$ due to the use of $20 \mathrm{t} \mathrm{ha}^{-1}$ of CMC, increasing from $7.00 \mathrm{~kg} \mathrm{~m}^{-2}$ in plots without fertilization at $8.72 \mathrm{~kg} \mathrm{~m}^{-2}$ in which they received 20 $\mathrm{t} \mathrm{ha}^{-1} \mathrm{CMC}$. This result shows that $\mathrm{CMC}$, due to its content of organic matter, nitrogen and other nutrients, fertilizes the soil, improves the growth rate; result that agrees with reports where the green forage yield was improved by the use of compost based on municipal solid waste [29], bovine manure [30], organic and inorganic fertilizer [27]; the content of organic matter is increased [30], with greater phosphorus mineralization [31]. Yield of 9.9 and $10.9 \mathrm{t} \mathrm{ha}^{-1}$ are reported in treatments with high compost application rates of 33.6 and $44.8 \mathrm{tha}^{-1}$, respectively [32], increasing the yield from $4.37 \mathrm{t} \mathrm{ha}^{-1}$ to $9.81 \mathrm{t} \mathrm{ha}^{-1}$ by the application of $\mathrm{N}_{200}$ compared to the control without fertilization [10].

\subsection{Dry Matter Yield}

The percentage of dry matter of ryegrass, 42 days after starting the experiment (first cut), was between 15.41 and $16.06 \%$, values that differ from other similar investigations [33], which report $37.5 \%$ dry matter in ryegrass. Probably due to the agroecological conditions of permanent soil moisture of the Yauris Experimental Farm, which allows the grass to have a higher water content. The DM yield was increased by 1.76 times by the use of $20 \mathrm{t} \mathrm{ha}^{-1}$ of $\mathrm{CMC}$ in front of the control $(\mathrm{P}<0.05)$, result of practical and economic importance, since it allows to increase the animal load and obtain greater productivity of grass.

At the second cut, the dry matter content of ryegrass was between 13.30 and $14.84 \%$, slightly lower values than the one recorded in the first cut. The yield of DM in $\mathrm{kg} \mathrm{m}^{-2}$ was 2.25 times more when incorporating $20 \mathrm{tha}^{-1}$ of CMC compared to the control without fertilization. These positive results using compost are reported by applying compost and residual effluents treated in an integrated manner, improving the production of DM from ryegrass [34]. Applying wastewater and olive pomace compost as soil amendments on the growth of the ryegrass, growth parameters were improved by 18.2 and $41.1 \%$ at the first and second year of production. A significant increase in total organic carbon, extracted and humidified, and in the humidification, parameters was determined. Ryegrass efficiently used the $\mathrm{N}$ content of the amendment and as a result significantly improved dry matter yield [35]. This proper handling of ryegrass fertilization allows obtaining $20 \mathrm{t} \mathrm{ha}^{-1}$ of DM [36], similar production obtained here by the use of $20 \mathrm{tha}^{-1}$ of CMC.

The increase in the yield of DM of ryegrass by CMC effect is of a lot of practical impact, because the contribution of nutrients (organic matter, protein, micronutrients) improves not only the consumption of food, but its digestibility and consequently the animal response; improves soil structure and better soil moisture retention [37]. Broiler chicken manure having a high content of nitrogen product, from high protein diets, between 22.5 to $19.5 \%$ [33] not only greatly improve the organic nitrogen content of the soil but also the contribution of $\mathrm{P}, \mathrm{K}, \mathrm{Ca}, \mathrm{Mg}, \mathrm{Na}, \mathrm{B}, \mathrm{Cu}, \mathrm{Zn}, \mathrm{Mn}$, $\mathrm{Fe}$, among other nutrients, increasing their availability for plants. Organic fertilizers provide between 2 and $4 \mathrm{~g}$ of phosphorus per kilogram, enough quantity for forage cultivation [38].

\subsection{Total Protein (TP) Yield}

The TP content, on a dry basis, at the first cut was between 15.6 to $18.4 \%$; equivalent to fresh content from 2.51 to $2.88 \%$. At the second cut, the percentage of PT on dry basis was between 16.6 and $20.4 \%$, equivalent to fresh values of 2.46 to $2.71 \%$; lower values reported in other experiments [30]; who report that ryegrass has an average of $3.11 \%$ of PT on a fresh basis. With these values the protein yield in $\mathrm{kg} \mathrm{m}^{-2}$ was determined.

At 42 days (first cut), the TP yield was increased by $28 \mathrm{~g} \mathrm{~m}^{-2}$ $(\mathrm{P}>0.05)$ when incorporating the CMC in $20 \mathrm{t} \mathrm{ha}^{-1}$, in relation to the plot that did not receive fertilization. At the second cut, made 42 days after the first cut and second fertilization, when incorporating $20 \mathrm{t} \mathrm{ha}^{-1}$ of CMC, the TP yield was increased by 104 $\mathrm{g} \mathrm{m}^{-2}(\mathrm{P}<0.05)$, with no effect for use of $10 \mathrm{t} \mathrm{ha}^{-1}$ of CMC. The increase in the yield of TP due to the use of $20 \mathrm{tha}^{-1}$ of CMC is of great nutritional and economic importance, because if we scale the results to one hectare, the ryegrass without fertilization, which would produce $1760 \mathrm{~kg}$ of PT ha-1, would rise to $2800 \mathrm{~kg}$ of PT $\mathrm{ha}^{-1}$ per cut, by incorporating $20 \mathrm{t} \mathrm{ha}^{-1}$ of CMC; it would have 1040 $\mathrm{kg}$ more of TP, which would allow greater supportability of the meadow and animal production.

These results demonstrate that the CMC would have a high potential for nitrogen available for crop uptake [39], being a good alternative for organic forage production and consequently for healthy livestock production, replacing the use of inorganic chemical fertilizers, contributing to the reduction of the negative environmental impact that it would have if the chicken manure is eliminated as garbage [17].

An additional aspect to consider is that in addition to the increase in the content and yield of TP of the ryegrass by the use of $20 \mathrm{tha}^{-1}$ of CMC, the content of organic matter is also improved, which rises up to $3 \%$ by use of bovine manure [30,27] satisfying the nitrogen requirement $(\mathrm{N})$ of the crops and providing other nutrients, such as phosphorus $(\mathrm{P})$, potassium $(\mathrm{K})$, calcium $(\mathrm{Ca})$ and magnesium $(\mathrm{Mg})$, reported in amendments made with animal waste [28, 40], improves the physical, chemical and biological characteristics of the soil, giving greater stability to the system [41]. 


\subsection{Plant Height (PH)}

At 42 days after the first application of the $\mathrm{CMC}$, the $\mathrm{PH}$ was significantly improved by the use of 10 and $20 \mathrm{t} \mathrm{ha}^{-1}$ compost $(\mathrm{P}<0.05)$. The PH increased by 7.06 and $7.82 \mathrm{~cm}$ due to increased use of the CMC. At the second cut, 42 days after the second fertilization, the $\mathrm{PH}$ was improved only in the treatment that considered the incorporation of $20 \mathrm{t} \mathrm{ha}^{-1}$ of CMC $(P<0.05)$, with no effect by the use of $10 \mathrm{t} \mathrm{ha}^{-1}$ of CMC; but the nutritional value was improved. The $\mathrm{PH}$ has a certain relationship with the dry matter yield [42].

The Plant Height registered in the present study was similar when different levels of N P K ( $\left.\mathrm{kg} \mathrm{ha}^{-1}\right)$ were used [43], the values were between 86 and $99 \mathrm{~cm}$ in fertilized pastures; while in the control treatment, without fertilization, the PH was only $62 \mathrm{~cm}$; at the Santa Ana-Huancayo Experimental Station (3316 altitude).

These results are of practical importance in animal feeding, since the $\mathrm{PH}$ is an indirect indicator of the condition of the pastures; the vigor of a grass can be evaluated by the $\mathrm{PH}$ and in the leaves, there is the highest digestible protein content for cattle.

The positive effect about the yield of biomass and protein of ryegrass by the amendment with $\mathrm{CMC}$, is a good alternative for livestock producers, contributing additionally with the recycling of chicken manure and with the carbon capture of the soil [44, 45], eliminating the use of nitrogen fertilizer and reducing the ecological impacts that endanger soil and air pollution [46, 47]; ryegrass cultivation being a good forage option, due to its high yield, nutritional quality and ability to grow in a great diversity of soils [17].

\section{Conclusion}

The yield of green forage, dry matter, total protein and ryegrass height were significantly improved $(P<0.05)$ when using $20 \mathrm{tha}^{-1}$ of chicken manure compost, being possible to replace inorganic fertilizers and obtain an organic forages production, reducing the negative impact by traditionally eliminating bird manure, in addition to improving soil condition.

\section{Acknowledgments}

The authors thank Dr Masataka Shimojo, Kyushu University, for experimental advice, Hermenegildo Dorregaray and technical staff of the Agricultural Farm of Yauris of the Universidad Nacional del Centro del Perú, for support during the experiment.

\section{Conflict of interest}

All the authors declare that there is no conflict of interests regarding the publication of this manuscript.

\section{References}

[1] FAO. La ganadería y el medio ambiente. FAO ed. Roma-Italia. 2019. http://www.fao.org/livestock-environment/es/.

[2] Aliaga, L., Moncayo, R., Rico, E. \& Caycedo, A. Producción de cuyes. Lima: Fondo Editorial de la Universidad Católica Sedes Sapientiae. Lima. Perú. $2009.808 \mathrm{p}$.

[3] DEIA. Compendio Estadístico Agropecuario de Junín 1,997 - 2,016. Dirección de Estadística e Información Agraria-Dirección General de
Agricultura de Junín. 2017. https://drive.google.com/file/d/0B6teYThL_oDqX2hBazIwVmlZbFk/view.

[4] SIEA, 2019. Sistema Integrado de Estadística Agraria. Datos en Excel Anuario de Producción Agrícola 2018. Ministerio de Agricultura. http://siea.minagri.gob.pe/siea/?q=noticias/anuario-de-produccion-agricola2018

[5] Saeid, A., \& Jastrzębska, M. Agronomic biofortification as a key to plant/cereal fortification in micronutrients. In: Food Biofortification Technologies [Internet]. CRC Press; 2017 [cited 2019 Jan 5]. p. 1-60. https://www.taylorfrancis.com/books/ 9781498756600/chapters/10.1201/9781351228350-1.

[6] Lidon, F. C., Oliveira, K., Ribeiro, M. M., Pelica, J., Pataco, I., Ramalho, J. C., et al. "Selenium biofortification of rice grains and implications on macronutrients quality". J Cereal Sci 81:22-9, 2018. DOI: https://doi.org/10.1016/j.jcs.2018.03.010.

[7] White, P. J., \& Broadley, M. R. "Biofortification of crops with seven mineral elements often lacking in human diets - iron, zinc, copper, calcium, magnesium, selenium and iodine". New Phytologist, 182: 49-84, 2009. https://doi.org/10.1111/j.1469-8137.2008.02738.x.

[8] Wang, Y. D., Wang, X., \& Wong, Y. S. Generation of selenium-enriched rice with enhanced grain yield, selenium content and bioavailability through fertilization with selenite. Chin. Univ. Food Chem. 141, 2385-2393, 2013. https://doi.org/10.1016/j. foodchem.2013.05.095.

[9] Kramberger, B., Gselman, A., Podvrsnik, M., Kristl, J., \& Lesnik, M. "Environmental advantages of binary mixtures of Trifolium incarnatum and Lolium multiflorum over individual pure stands". Plant, Soil and Enviroment vol. 59:22-28, 2013

[10] Rechițean, D., M. Dragoș, N. Dragomir, M. Horablaga, M. Sauer, D. Camen, I. Toth, \& A. Sala. "Associated Culture of Italian Ryegrass (Lolium multiflorum) and Crimson Clover (Trifolium incarnatum) under Nitrogen Fertilization". Animal Science and Biotechnologies. 51(1):129-132, 2018.

[11] Cueto, W. J., Quiroga, G. H., \& Becerra, M. C. "Nitrógeno disponible y desarrollo del ballico anual. 1. Producción, calidad del forraje y acumulación de nitratos". Terra. 21(2): 285-295, 2003.

[12] Brack, A., \& Mendiola C. La contaminación ambiental, Enciclopedia Virtual "Ecología del Perú". Disponible en: http://www.peruecologico.com.pe/libro.htm.Tomado el 20/ene/2019.

[13] Cortijo, E., Faure, G., \& Le Gal. P. Inserción de las pequeñas explotaciones familiares en la cadena de suministro de los lácteos en el Valle del Mantaro (Perú): hacia una gestión de apoyo que tome en cuenta la diversidad de los actores. Cirad. La Recherche Agronomique Pour le Développement. 2010. http://siteresources.worldbank.org/EXTSOCIAL DEVELOPMENT/Resources/244362-1265299949041/67663281308081363318/Dairy-Study-Final-SPA-ENG.pdf.

[14] Gordillo, F., Peralta, E., Chavez, E., Contreras, V., Campuzano, A., \& Ruiz, O. "Producción y evaluación del proceso de compostaje a partir de desechos agroindustriales de Saccharum officinarum (caña de azucar)". RIA. 37(2):140-149, 2011. https://www.redalyc.org/articulo.oa?id=86421189006.

[15] Pinos-Rodríguez, J. M., García-López, J. C., Peña-Avelino, L. Y., RendónHuerta, J. A., González-González, C., \& Tristán-Patiño, F. (2012). Impactos y regulaciones ambientales del estiércol generado por los sistemas ganaderos de algunos países de América. Agrociencia 46: 359-370.

[16] Kupper, T., Bürge, D., Bachmann, H. J., Güsewell, S., \& Mayer, J. Heavy metals in source-separated compost and digestates. Waste Management, 34(5), 867-874, 2014. https://doi.org/10.1016/j.wasman.2014.02.007

[17] Riera, N. I., Della Torre, V., Rizzo, P. F., Butti, M., Bressan, F. M., Zárate, N., Weigandt, C. \& Crespo, D. "Evaluación del proceso de compostaje de dos mezclas de residuos avícolas". Rev FCA UNCUYO 46(1):195-203, $2014 . \quad$ http://revista.fca.uncu.edu.ar/images/ stories/pdfs/201401/Cp14_Riera.pdf.

[18] Bustamante, C., Gutiérrez, E., Malla, J., Palacios, R., \& Revilla, F. Planeamiento Estratégico para el Subsector del Pollo de Engorde en el Perú. Tesis Magíster Administración de Negocios Globales. 2018. EPG-PUCP. http:/tesis.pucp.edu.pe/repositorio/bitstream/handle/123456789/11641/BUS TAMANTE_GUTIERREZ_PLANEAMIENTO_POLLO.pdf? sequence $=1$.

[19] aviNews. Avicultura de Perú continúa creciendo este año 2019. La Revista Global de Avicultura. https://avicultura.info/avicultura-de-peru-continuacreciendo-este-ano-2019/

[20] Huff, W. E., Malone, G. W., \& Chaloupka, G. W. "Effect of litter treatment on broiler performance and certain litter quality parameters". Poult. Sci. 63:2167-2171, 1984.

[21] Nahm, K. H. "Evaluation of the nitrogen content in poultry manure". Worlds Poult. Sci. J. 59:77-88, 2003. 
[22] Ruiz Diaz, D. A., Sawyer, J. E., \& Mallarino, A. P. "Poultry Manure Supply of Potentially Available Nitrogen with Soil Incubation". Agronomy Journal, 100(5):1310, 2008. doi:10.2134/agronj2007.0371.

[23] San Fernando. Compost de Guano de Pollo, Compuesto Natural. Mejorador de suelos. San Fernando S.A. Lima. Perú. 2007.

[24] Mamani, E., Jiménez, A. R., San Martín, H. F., Huamán, U. H., Ara, G. M., Carcelén, C., \& Huamán, C. A. "Determinación del periodo óptimo de descanso de la pastura asociada Lolium multiflorum, Trifulium pratense y Medicago sativa, pastoreada por cuyes en la sierra central del Perú". Revista de Investigaciones Veterinarias del Perú, 26(3):404-411, 2015. https://dx.doi.org/10.15381/rivep.v26i3.11174.

[25] Ferret, A. "Control de calidad de forrajes". En: XIX curso de especialización FEDNA. Madrid. Fundación Española para el desarrollo de la nutrición animal. 2003. http://fundacionfedna.org/sites/default/files/03CAP_VII.pdf.

[26] AOAC. Official Methods of Analysis of the Association of Official Analytical Chemists. Vol 1. 15th ed. Washington DC: AOAC. 1990. 1298 p.

[27] Hernández, M. T., Chocano, C., Melgares, J., González, D., \& García, C. "Incidencia de enmiendas orgánicas sobre la calidad del suelo en ciruelo ecológico". VII Congreso SEAE. Zaragoza, España N²6, 2006. https://docplayer.es/72880188-Incidencia-de-enmiendas-organicas-sobre-lacalidad-del-suelo-en-ciruelo-ecologico.html.

[28] Aguirre, M. E., Bussetti, S. G., \& Santa María, R. M. "Fósforo hidrosoluble y disponible en el suelo por el agregado de cáscara de girasol". Rev. Inv. Fac. Cienc. Agra. 11:1-6. 2007

[29] Herencia, J. F., Ruiz, P. J., Melero, P. S., García Galvis, A., Morillo, E., \& Maqueda, C. "Comparison between organic and mineral fertilization for soil fertility levels, crop macronutrient concentrations and yield". Agron J. 99: 973-983, 2007.

[30] Salazar, S. E., Trejo, E. H., López, M. J., Vázquez, V. C., Serrato, C. J., Orona, C. I., \& Flores, M. J. "Efecto residual de estiércol bovino sobre el rendimiento de maíz forrajero y propiedades del suelo". Terra Latinoamericana. 28: 381390, 2010.

[31] Jiménez, L., Larreal, M., \& Noguera, N. "Efectos del estiércol de bovino sobre algunas propiedades químicas de un Untisol degradado en el área de la Machiques Colón, estado de Zulia”. Rev. Fac. Agron. (Luz)21:1-11, 2004.

[32] Smiciklas, K. D., Walker, P. M., \& Kelley, T. R. "Evaluation of compost for use as a soil amendment in corn and soybean production". Compost Science and Utilization 16(3):183-191, 2008.

[33] Castro, J., \& Chirinos, D. Manual de Formulación de Raciones Balanceadas Para Animales. 2008. Concytec. 230 p.

[34] Chipula, G., Sakrabani, R., Hess, T., \& Tyrrel, S. "Compost-Sewage Effluent Integration for Ryegrass Production. Journal of Crop Improvement" 28(3):345-360, 2014. DOI:10.1080/15427528.2014.888532).

[35] Montemurro, F., Convertini, G., \& Ferri, D. "Mill wastewater and olive pomace compost as amendments for rye-grass". Agronomie, EDP Sciences; 24 (8):481-486, 2004.

[36] Donaghy, D., \& Fulkerson, B. Principles for developing an effective grazing management system for ryegrass-based pastures. Tasmanian Institute of Agricultural Research, Burnie, Tasmania. 2001. 10 p.

[37] Moral, R., Paredes, C., Bustamante, M., Marhuenda-Egea, A.F., \& Bernal, M.P. "Utilization of manure composts by high-value crops: Safety and environmental challenges". Bioresource Technology 100(22): 5454-5460, 2009.

[38] Eghball, B. "Soil properties as influenced by phosphorus- and nitrogen- based manure and compost applications". Agron. J. 94: 128-135, 2002.

[39] Nahm, K. H. "Factors influencing nitrogen mineralization during poultry litter composting and calculations for available nitrogen". Worlds Poult. Sci. J. 61:238-255, 2005

[40] Pérez, A., Céspedes, C., \& Núñez, P. “Caracterización física-química y biológica de enmiendas orgánicas aplicadas en la producción de cultivos en República Dominicana”. R.C. Suelo Nutr. Veg. 8(3):10-29, 2008.

[41] Donn, S., Wheatley, R., McKenzie, B., Loades, K., \& Hallett, P. "Improved soil fertility from compost amendment increases root growth and reinforcement of surface soil on slopes". Ecological Engineering, 71:458-465, $2014 . \quad$ http://www.sciencedirect.com/science/ article/pii/S0925857414003577.

[42] Villalobos, L., \& Sánchez, J. "Evaluación agronómica y nutricional del pasto Rye grass perenne tetraploide (Lolium perenne) producido en lecherías de las zonas altas de Costa Rica: Producción de biomasa y fenología". Agronomía Costarricense 34(1): $\quad 31-42, \quad 2010 . \quad$ ISSN:0377-9424. http://www.scielo.sa.cr/pdf/ac/v34n1/a03v34n1.pdf.

[43] Nestares, P. A., Camargo, S. M., \& Rojas, S. A. Producción de semillas de Rye grass italiano con riego tecnificado. INIA. EEA Santa Ana. Huancayo, 1992.
https://alicia.concytec.gob.pe/vufind/Record/INIA 73365a37167df77a238e3 ebeb2c0eb02.

[44] Fowler, C. J., Condron, L. M., \& McLenaghen, R. D. "Effect of green manures on nitrogen loss and availability in organic cropping system". New Zealand J. Agri. Res. 47, 95-100, 2004

[45] Zhang, M., Gavalak, R., Mitchell, A., \& Sparrow, S. "Solid and liquid cattle manure application in a subartic soil". Agron. J. 98, 1551-1558, 2006.

[46] Zhang, H., Xu, M., \& Zhang, F. "Long-term effects of manure application on grain yield under different cropping system and ecological conditions in China". J. Agric. Sci. 2009, 147, 31-42, 2007.

[47] Jacinthe, P. A., \& Lal, R. "Carbon storage and minesoil properties in relation to topsoil application techniques". Soil Sci. Soc. Am. J. 71, 1788-1795; 2007. 